\title{
Income Diversification, Inequality and Poverty among Rural Households in Oyo State, Nigeria
}

\author{
${ }^{1}$ Olubunmi O. Alawode, ${ }^{2}$ Isaac B. Oluwatayo, ${ }^{1 *}$ Afusat O. Abdullahi \\ ${ }^{1}$ Department of Agricultural Economics, University of Ibadan, Nigeria \\ ${ }^{2}$ Department of Agricultural Economics and Animal Production, University of Limpopo, South Africa \\ *isaac.oluwatayo@ul.ac.za
}

\begin{abstract}
The study examined income diversification, inequality and poverty among rural households in Oyo state, Nigeria. Cross-section data were generated from the survey conducted on a sample of 200 households with the aid of structured questionnaire using multi-stage sampling procedure. Descriptive statistics, diversification index, Gini coefficient, FGT poverty index, and the Probit regression model were used to analyze data. Mean income diversification index of 1.22 shows that majority of the respondents had multiple streams of income but crop farming had the largest share $(90 \%)$ in total income. Mean income of respondents was $\$ 77,613.2 \pm 83575.01$, and Gini coefficient of $0.48,0.46$, and 0.39 were obtained for total income, nonagricultural income, and agricultural income respectively. The poverty line was $\$ 6,490.50$ and mean per capita expenditure was $\$ 9,735.74$. The head count ratio showed that $53.5 \%$ of the households were poor while $46.5 \%$ were regarded as non-poor, and poverty gap was 0.214 . From probit results, age, secondary occupation, and farm size had significant inverse relationship with poverty status. Having primary and secondary income sources is poverty reducing, therefore, rural households should be encouraged to remain in farming, especially crop farming, and motivated through skill acquisition to diversify into other income generating activities.
\end{abstract}

Keywords: Income diversification, Inequality, Poverty, Income sources, Non-agricultural activities

\section{Introduction}

Poverty is lack of job, hunger, poor health, low education, low self-esteem, lack of adequate housing, lack of land, low economic status, and inability to clothe oneself and family (Adigun et al., 2011). According to Lawal et al. (2011), poverty creates frustration, loss of hope/prospects and value for life, loss of meaning for life and purpose of living. Poverty also creates disillusionment about morality as it makes people compromise on moral values or abandon moral values completely. Okafor (2004) affirmed that the success or failure of any government is measured by the degree of attainment of human development or the level of poverty prevalent among the people. The notions of income distribution have been a subject of immense concern to economists for a long time. This is because high level of income inequality produces an unfavorable environment for economic growth and development (British Council, 2012). Previous studies have shown that income inequality has risen in many developing countries in the last two decades, leading to pockets of poverty situation across the world (Clarke et al., 2003). In Nigeria, though there has been multiplicity of programs and projects with poverty reduction mandate implemented over the years, it appears they were tinkering at the edges rather than the root causes of poverty since its incidence and severity had continued to deepen (Nwachukwu and Ezeh, 2007).

According to British Council (2012), Nigeria is a country with the largest population on the African continent with 162.5 million people, and it is among the thirty most unequal countries in the world with respect to income distribution, where the poorest half of the population holds only $10 \%$ of national income. More disturbing is the fact that $54 \%$ of Nigerians still live in poverty and the proportion has doubled since 1980 , when about $28 \%$ were classified as poor. Human development indicators are also worse than those of comparable lower middle-income countries; $42 \%$ of Nigerian children are malnourished (Idowu et al., 2011). The average poverty incidence in Nigeria increased from 0.28 to 0.42 between 1980 and 1992 respectively, and by 1996, the situation worsened to an average of 0.66. By implication, out of every 100 Nigerians, 66 were dwelling below the poverty line with great difficulties (Nwachukwu and Ezeh, 2007; National Poverty Alleviation Program, 2006). The Nigerian economy is characterized by a large rural, mostly agriculture based traditional sector, which is home to about three-quarters of the poor. According to the International Fund for Agricultural Development (IFAD, 2009), the farm sector employs about two-thirds of the country's total labor force and provides livelihood for about $90 \%$ of the rural population. Agriculture is plagued with various problems, and as a result, most of the rural households are poor, and are diversifying their livelihoods into 
non-farm activities as a relevant source of income (Adepoju and Obayelu, 2013). This implies that despite agriculture being the major occupation, non-farm sector plays several roles in the development of the rural sector (Lanjouw, 2001).

The rural economy is not based solely on agriculture but rather on a diverse array of activities and enterprises. Diversification has been defined by Kimenju and Tschirley (2008) as the number of economic activities an economic unit is involved in and the dispersion of those activities' shares in the total economic activities of the unit. The focus on livelihood is relevant, in particular with the discussion on rural poverty reduction. With prevalent poverty in most rural areas, rural development has been an important policy goal for many developing countries (Hyewon, 2011).Africans diversify their livelihood strategies, including onfarm (crop, livestock and fisheries) and off-farm activities, or market and non-market activities, to mitigate risks inherent in unpredictable agro-climatic and politico-economic circumstances (Bryceson, 2002). Off-farm activities have become important component of livelihood strategies among rural households in most developing countries. According to Lanjouw and Lanjouw (2001), many smallholder farm households complement their farm income with income from non-farm sources. This strategy has several advantages, especially for poorer households. Their agricultural resources are often too limited to allow the productive use of all household labor, and non-farm activities offer an alternative remunerative allocation, especially during the lean agricultural season. Moreover, income from agriculture is subject to high risk due to climatic factors, price fluctuations, pests, and diseases. Earnings from non-farm employment may help to buffer the resulting income fluctuations and improve livelihood security.

In Nigeria, the rate of poverty reduction achieved from various poverty reduction strategies adopted is far below what is required to achieve the poverty reduction goal of the Millennium Development Goals (Nuhu, 2007). Burgeoning literature on livelihood diversification across the developing world has pointed to the increasing role of non-farm incomes in poverty reduction (Bryceson, 1996). Therefore, the concept of livelihood diversification as a survival strategy of rural households in developing countries (Ellis, 1999), and exploiting these off-farm opportunities could offer pathway out of poverty for the rural poor (Barrett et al., 2001). As diversification is not an end by itself, it is essential to connect observed patterns of income to resulting income distribution and poverty. According to Jonasson (2005) and Awoyemi (2004), the contribution of non-farm economic activities in rural economy cannot be neglected because it has grown substantially from $30 \%$ to $50 \%$ in the developing economies during the last two decades. In this respect, the behavior of rural households towards diversifying their sources of income and employment in favor of nonagricultural activities could be considered as an important requirement for rural poverty reduction in Nigeria. It is therefore imperative to examine the contribution of non-farm economic activities to household income and also look into the relationship among income diversification, inequality and poverty. The broad objective of this study is to examine income inequality and the effect of income diversification on poverty status of rural households in Oyo state. The specific objectives are to examine the sources of income generating activities, analyze income diversification and inequality, and poverty status of the households, and determine the effect of income diversification on the poverty status of rural households. Through the results emanating from this study, policy makers would be informed on steps to take in alleviating poverty among rural households. Also, non-governmental organizations will have better knowledge on where to focus their efforts.

\section{Methodology}

The study was carried out in Oyo state, Nigeria. It belongs to the western region since the days of the British colonial rule in Nigeria. From the census results of the National Population Commission (2006), Oyo state has an estimated population of over 5,591,589 million people. The state is located in the rain forest vegetation belt of Nigeria within longitude $7023^{\prime} 47^{\prime \prime} \mathrm{N}$ and $3055^{\prime} 0^{\prime \prime}$. It is bounded in the south by Ogun state and in the north by Kwara state, in the west by the Republic of Benin while in the east by Osun state. As stated by Oyo State Agricultural Development Program (OYSADEP, 2001), the state has a land area of approximately $28,454 \mathrm{~km}^{2}$, and there are four ADP Zones; Saki, Ogbomoso, Oyo and Ibadan/Ibarapa. Oyo state exhibits the typical climate of averagely high temperature, high relative humidity, and generally two rainfall maxima regimes during the rainfall period of March to October. 
A multi-stage (four-stage) sampling procedure was used to select the respondents. A total of 200 households were involved in the study. The first stage was the random selection of Ogbomoso and Ibadan/Ibarapa Zones. The second stage was the simple random selection of Oriire and Ogo-Oluwa local government areas from Ogbomoso zone, while Akinyele and Ido local government areas were selected from Ibadan/Ibarapa zone. Five villages were randomly selected from Ogo-Oluwa local government area; Ajaawa, Eleepa, Otamakun, Ayegun-Yemetu, and Ayegun-Araromi. Also, five villages were randomly selected from Oriire local government area; Tewure, Ikoyi-ile, Adafila, Abogunde and Iluju. Seven villages were randomly selected from Ido local government area; Olokogbooro, Abegunrin, Adegbolu, Koguo, Alapata, Eleshinfunfun and Abigbinde, and six villages were randomly selected from Akinyele local government area; Ajeja, Alaro, Alabata, Elekun, Olorisa-Oko, and Ijaye. Finally, fifty households were randomly selected from each local government area. Primary data were collected with the use of structured questionnaire which was administered to the respondents.

Analytical Techniques: Data collected were analyzed using descriptive and inferential statistics. The socioeconomic characteristics of the respondents were analyzed using descriptive statistics such as frequency distribution and percentages, and the result are presented in frequency distribution tables. The objectives were analyzed as follows:

Sources of income generating activities: The descriptive statistics such as mean, frequency distribution and percentages were used to summarize and describe the sources of income generating activities among rural households

Income Diversification: Shares of household income derived from various farm and non-farm sources as well as the inverse of the Herfindahl index of overall income diversification was obtained, following Oyewole et al., (2015), Kaija (2007) and Ersado (2006) as Follows;

$\mathrm{D}=\left[\sum_{\mathrm{j}=1}^{\mathrm{n}} \mathrm{S}_{\mathrm{J}}^{\alpha}\right]^{1 / 1-\alpha}$

$\mathrm{Y}_{\mathrm{J}} \sum_{j=1}^{n} y_{j}$

$\alpha$ is the diversity parameter such that $\alpha \geq 0$ and $\alpha \neq 1$ for $\alpha=2$, the index D becomes the inverse of herfindhahl index which is commonly used as income diversification index. The income diversification index used in the study was defined as the inverse of the herfindahl index as follows;

$\mathrm{D}=\frac{1}{\sum_{j=1}^{n} s_{J}^{2}}$

Where

$\mathrm{D}=$ Diversity index

$\mathrm{Sj}=$ Share of income source with respect to the total income

$\mathrm{Yj}=$ Total income from source $\mathrm{j}$

$Y=\sum_{j=i}^{n} Y j$ is total household income from all sources; $\mathrm{j}=1,2,3 \ldots . \mathrm{n}$.

$\alpha=$ Diversity parameter, such as $\alpha \geq 0$ and $\alpha=1,2$ and 3 .

The diversification index ranges between 0 and 1 . If there is lack of diversity, the index is unity. So the degree of diversification depends on the amount by which diversity index exceeds unity.

Income inequality: This was used to show the degree of income inequality, between different households in the population. The Gini coefficient is a precise way of measuring the position of the Lorenz curve. It has a value between 0 and 1 and it is worked out by measuring the ratio of the area between the Lorenz curve and the $45^{\circ}$ line to the whole area below the $45^{\circ}$ line. If the Lorenz curve is the $45^{\circ}$ line, then the value of the Gini coefficient would be zero. In general, the closer the Lorenz curve is to the line of perfect equality, the less the inequality and the smaller the Gini coefficient. The Gini coefficient is computed as:

$$
I_{\text {gin }}(Y)=\frac{2 \sum_{i=1}^{n}}{n^{2} \mu} i\left[-\frac{n+1}{2}\right] Y i
$$

Where; $\mathrm{n}=$ number of observations, $\mu=$ mean of the distribution

$$
\mathrm{y}_{\mathrm{i}}=\text { income of the household, } \quad \mathrm{I}_{\mathrm{gini}}=\text { Income Gini }
$$

A gini coefficient of 0 expresses perfect equality, where all values are the same (that is, everyone has an exactly equal income). A gini coefficient of 1 expresses maximal inequality among values (where only one 
person has all the income). The determination of income inequality by gini coefficient was done using DASP Software on Stata. The Gini Coefficient formula is in line with Wilson et al. (2010), Madu (2006) and Damgaard and Weiner (2000). For this study, the gini coefficient for total income (gotten from agricultural activity, non-agricultural activity and remittances), income from agricultural activities only, and income from non-agricultural activities only, were obtained.

Poverty status of farm households: FGT poverty index was employed to ascertain the poverty status of the respondents and this was used to disaggregate them into poor and non-poor categories. It has become customary to use the $\mathrm{P}_{\alpha}$ measures in analyzing poverty. Following the adoption of Foster, Greer and Thorbecke FGT (1984) class of poverty measures, households' total monthly expenditure was used to determine households' poverty status. The poverty line was constructed as two-thirds of the mean monthly per-capita expenditure of all households. This approach has been used by individuals and institutions, for example, Alawode et al. (2016), Yusuf and Oni (2008) and NBS(2005). Hence, non-poor households are those whose monthly expenditure is above or equal to two-thirds of the mean per capita expenditure of all households while those whose per capita expenditure was below two-thirds of the mean monthly per capita expenditure were classified as poor. The measures relate to different dimensions of the incidence of poverty. $\mathrm{P}_{0}, \mathrm{P}_{1}$ and $\mathrm{P}_{2}$ were used for head count (incidence), depth and severity of poverty respectively. The three measures were based on a single formula but each index puts different weights on the degree to which a household or individual falls below the poverty line. The mathematical formulation of poverty measurements as derived from Foster, Greer and Thorbecke (1984) is estimated as:

$\mathrm{H}=\mathrm{q} / \mathrm{n}$

Where; $\mathrm{H}=$ head count ratio (poverty incidence)

$q=$ number of poor households that fall below the poverty line.

$\mathrm{n}=$ total number of rural household

Poverty gap index usually measures poverty depth and the formula below was adopted

where ;

$$
\mathrm{p} \alpha=\frac{1}{N} \sum_{i=1}^{q} \frac{Z_{-Y}}{Z}
$$

$\mathrm{p}_{\alpha}=$ poverty gap

$\mathrm{Z}=$ poverty line estimated using mean household expenditure

$\mathrm{Y}=$ average expenditure of the poor rural farm household

If $\alpha=0$, then FGT measures the incidence of poverty

If $\alpha=1$, then FGT measures the depth of poverty

If $\alpha=2$, then FGT measures the severity of poverty

The headcount index $\left(\mathrm{P}_{0}\right)$ simply measures the proportion of the population that is counted as poor. The poverty gap index adds up the extent to which individuals on average fall below the poverty line, and expresses it as a percentage of the poverty line. The poverty gap $\left(\mathrm{P}_{1}\right)$ is specifically regarded as the poverty line $(\mathrm{z})$ less actual income $\left(\mathrm{y}_{\mathrm{i}}\right)$ for poor individuals; the gap is considered to be zero for everyone else. It shows how much would have to be transferred to the poor to bring their incomes or expenditures up to the poverty line (as a proportion of the poverty line).The poverty severity is a weighted sum of poverty gaps (as a proportion of the poverty line), where the weights are the proportionate poverty gaps themselves, this is in contrast with the poverty gap index, where they are weighted equally. Hence, by squaring the poverty gap index, the measure implicitly puts more weight on observations that fall below the poverty line. Hence, the higher the value of $\alpha$, the greater the weight placed on the poorest individual. The higher the FGT statistics, the more poverty there is in the rural household.

Effect of income diversification on poverty status of rural households: The probit regression model was used to determine the effect of income diversification on poverty status among rural households. It examined the relationship between the probability of a rural household being poor or non-poor with a number of explanatory variables. Following Rahji and Fakayode (2009), the model is specified as:

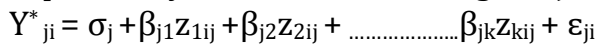

$Y^{*} \sigma_{j}$ remains constant across alternatives

$\beta_{\mathrm{jk}}$ is a regression coefficient associated with the $\mathrm{jth}$ explanatory variable and the kth outcome for $\mathrm{j}=$ $1,2,3, \ldots \ldots \ldots . . . j-1$ 
$\varepsilon_{\mathrm{ji}}$ is a random error term reflecting intrinsically random choice. Where:

$\mathrm{Y}=$ Poverty status of households (Poor $=1,0$ otherwise).

The independent variables include:

$\mathrm{Z}_{1}=$ Age of the respondents (years), $\mathrm{Z}_{2}=$ Household size (number), $\mathrm{Z}_{3}=$ Primary occupation of the respondent (agricultural $=1,0$ if otherwise), $\mathrm{Z}_{4}=$ Secondary occupation of the respondent (non-agricultural=1, 0 if otherwise), $\mathrm{Z}_{5}=$ Farm size (ha), $\mathrm{Z}_{6}=$ Membership of society (members=1,0 if otherwise), $\mathrm{Z}_{7}=$ Gender of household head (male $=1,0$ if otherwise), $\mathrm{Z}_{8}=$ Marital status (married $=1,0$ if otherwise), $\mathrm{Z}_{9}=$ Years of

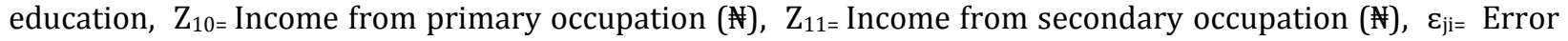
term.

The coefficients may be positively or negatively significant or insignificant. A positive significant variable means that a percentage change in the independent variable will increase the probability of being poor by value of the coefficient, and a negatively significant variable is interpreted that a percentage change in the variable will reduce the probability of being poor by the value of the coefficient. The apriori expectation indicates that age of the respondents, primary occupation, secondary occupation, farm size, membership of society and years of education could have inverse relationship with poverty; while household size, gender of household head, and marital status might be directly linked to poverty.

\section{Results and Discussion}

Table 1: Income generating activities among rural households

\begin{tabular}{lllll}
\hline \multicolumn{2}{l}{ Activities } & \multicolumn{2}{c}{ Primary occupation } & \multicolumn{2}{l}{$\begin{array}{l}\text { Secondary occupation } \\
\text { Frequency }\end{array}$} & Percentage & Frequency & Percentage \\
\hline Agricultural activities & & & & \\
Crop farming & 151 & 75.5 & 1 & 0.5 \\
Livestock farming & 13 & 6.5 & 0 & 0.0 \\
Processing & 7 & 3.5 & 0 & 0.0 \\
Fishery & 4 & 2.0 & 1 & 0.5 \\
Hunting & 0 & 0.0 & 2 & 1.0 \\
Non-agricultural activities & & & & \\
Private salaried job & 0 & 0.0 & 8 & 4.0 \\
Artisans & 12 & 6.0 & 66 & 33.0 \\
Trading & 7 & 3.5 & 38 & 19.0 \\
Civil service & 3 & 1.5 & 5 & 2.5 \\
Transporters & 1 & 0.5 & 14 & 7.0 \\
Self employed & 1 & 0.5 & 4 & 2.0 \\
Clergy & 1 & 0.5 & 1 & 0.5 \\
None & 0 & 0.0 & 60 & 30.0 \\
Total & 200 & 100 & 200 & 100 \\
\hline
\end{tabular}

Source: Field Survey, 2016

Income generating activities among rural households: The income generating activities among the rural households are presented in Table 1. The activities were grouped into agricultural and non-agricultural activities which are primary or secondary activities to the respondents. Results show that more than three quarter $(75.5 \%)$ of the respondents were engaged in crop farming as their primary occupation. This is expected as most households in the rural areas depend mainly on agriculture as their main source of livelihood. The crop farmers planted vegetables, yam, cassava, plantain, maize, pepper, tomatoes, and so on. More than $30 \%$ of the respondents did not have secondary income generating activities while about (70\%) of the respondents engaged in a combination of different livelihood activities. From those who had secondary income generating activity, majority of them (33\%) were artisans. These artisans include; tailors, hairdressers, barbers, welders, basket weavers, vulcanizers, mechanics, shoe makers, carpenters and painters. This shows that majority of the respondents diversified from agricultural livelihood activities to non-agricultural activities. Respondents had various reasons for diversifying into other income generating activities. However, the most pertinent reason for diversification was limited income due to seasonal factor of agricultural produce, diseases, pests and large number of dependents. 
Income diversification and inequality among the rural households: From Table 2, majority (55.6\%) of the households were engaged in farming activities either as primary occupation, secondary occupation or both. Crop farming had the largest share of about $90 \%$ in total income. This corresponds with the findings of International Fund for Agricultural development (IFAD, 2009). The remaining (10\%) of the total income was shared among other livelihood sources with processing ranking highest $(3 \%)$. The results also show that majority of the respondents were engaged in farming activities, and they generated more income from it, hence the large dominance of income from farming activities in the total income. The herfindahl diversification index obtained was 0.82 which further ascertained that the income generated from farming activities strongly dominates other income sources. Hunting and clergy as a means of livelihood contributed the least to the total income. Meanwhile, 30\% had diversity index of 1, implying that these households did not diversify their income sources. The mean income diversification index was 1.22 , which implies that an average respondent in the study area was involved in different types of income-generating activities simultaneously. On the average, a respondent was involved in at least one farming activity and one non-farm activity.

Table 2: Livelihood sources and income of respondents

\begin{tabular}{|c|c|c|c|c|c|}
\hline livelihood activities & frequency & percentage & $\begin{array}{l}\text { Income of } \\
\text { respondents per } \\
\text { month }\end{array}$ & $\mathbf{S i}$ & $\mathbf{S i}^{2}$ \\
\hline \multicolumn{6}{|l|}{ Agricultural activities } \\
\hline Livestock farming & 13 & 4.8 & 911666.67 & 0.00726 & 0.000053 \\
\hline Crop farming & 152 & 55.6 & 113485000 & 0.90358 & 0.816445 \\
\hline Fishery & 5 & 1.9 & 2633000 & 0.020964 & 0.000439 \\
\hline Processing & 7 & 2.6 & 3772000 & 0.03003 & 0.000902 \\
\hline Hunting & 2 & 0.7 & 30000 & 0.00024 & 0.0000006 \\
\hline \multicolumn{6}{|c|}{ Non-agricultural activities } \\
\hline Trading & 45 & 16.6 & 2311000 & 0.0184 & 0.0003386 \\
\hline Civil service & 8 & 3.0 & 357000 & 0.00284 & 0.00000081 \\
\hline Private salaried jobs & 8 & 3.0 & 89000 & 0.00071 & 0.00000050 \\
\hline Artisans & 78 & 28.9 & 1500600 & 0.01195 & 0.000142 \\
\hline Self employed & 5 & 1.9 & 62000 & 0.00049 & 0.00000024 \\
\hline Transporters & 15 & 5.5 & 373000 & 0.00297 & 0.0000088 \\
\hline Clergy & 2 & 0.7 & 70000 & 0.00056 & 0.0000003 \\
\hline Total & 260 & 100 & 125594266.7 & 1 & 0.82 \\
\hline
\end{tabular}

Source: Field Survey, 2016

* The total of 260 was due to the multiple jobs held by some of the respondents.

Income inequality: In estimating the income inequality of the households, Gini coefficient was computed for total income (which include agricultural income, non-agricultural income and remittance), income from agricultural source, and income from non-agricultural source. The results are presented in Table 3 . The mean income of respondents was $\$ 77,613.20 \pm 83,575.01$. Also, the Gini coefficient obtained for total income was 0.48 (significant at 1\%) and it reflects the level of inequalities in income distribution. This is similar to the Gini coefficients of 0.449 and 0.488 for Southeast and Nigeria respectively as reported by National Bureau of Statistics (NBS, 2005) and Aigbokhan (2008). Invariably, the gap between the rich and the poor was not so high among the rural households. The gini coefficients for agricultural income and non-agricultural income were 0.39 and 0.46 (significant at 1\%). This implies that inequality was higher among households that earned non-agricultural than agricultural income generating activities, while inequality was highest for total income (including remittance). This may be due to a wide disparity between remittances obtained by household or overall effect of all income sources. 
Table 3: Income inequality among the rural household

\begin{tabular}{|c|c|}
\hline Income/Gini coefficient & Estimates \\
\hline $\begin{array}{l}\text { Mean income per month } \\
\text { Gini Coefficient }\end{array}$ & N77,613.21 \\
\hline Total income & 0.48 \\
\hline Agricultural income & 0.39 \\
\hline Non-agricultural income & 0.46 \\
\hline
\end{tabular}

Source: Data Analysis, 2016

Poverty status of respondents: From the results in Table 4, the mean expenditure was $\$ 50,433.50$. The poverty line was estimated to be $\$ 6,490.50$ which was computed as the two-third of the mean per capita expenditure of $\$ 9,735.74$. Any household with monthly expenditure below the poverty line is classified as poor while household with expenditure equal to or greater than the poverty line is classified as non-poor. The head count ratio shows that $53.5 \%$ of the households were poor while $46.5 \%$ were regarded as non-poor. This implies that more households fell below the poverty line in the study area. The poverty gap of 0.214 was obtained. This can be compared with the poverty gap index of 0.12 for south-east geographical zone in 2004 reported by Omonona (2010).It is a measure of poverty deficit of the entire population. Poverty severity index was 0.108 , this takes into account not only the distance separating the poor from non-poor households but also the inequality among the poor. The result is similar with the findings of Asogwa et al. (2012) who reported a poverty gap of 0.27 and poverty severity of 0.15 among farming households in Nigeria.

Table 4: Expenditure and Poverty indices of respondents

\begin{tabular}{ll}
\hline Expenditure/Poverty variables & Estimates \\
\hline Mean expenditure per month & $\$ 50,433.50$ \\
Poverty line & $\$ 6,490.50$ \\
Per capita expenditure & $\$ 1,947,15$ \\
Mean per capita expenditure & 0.535 \\
Head count index & 0.214 \\
Poverty gap & 0.108 \\
\hline
\end{tabular}

Source: Data Analysis, 2016

Effect of income diversification on poverty status: The probit regression results on the effects of income diversification on poverty status are presented in Table 5. The overall model had a good fit and it was significant at $1 \%$. Age had significant relationship with poverty status at $5 \%$ and decreases the probability of being poor by 0.0128 , implying that age reduces the probability of being poor. Household size was significant at $1 \%$. A unit increase in household size will increase the probability of being poor by 0.175 . This indicates that the larger the household size, the higher the probability of being poor. This is imperative because larger household size, especially more dependents, would require higher expenditure, hence, increase the chances of being poor. Being involved in agricultural activity as primary occupation, especially crop farming, reduces the probability of being poor by 0.1 . Also, diversification into non-agricultural livelihood activity as secondary occupation had a probability of reducing poverty by 0.162 at $10 \%$ level of significance. This implies that being involved in agricultural activities as primary occupation and non-agricultural activity as secondary occupation reduces poverty. Since both categories of occupation have the likelihood to reduce poverty level, this means that households who diversify their income would further move away from poverty.

Being a member of co-operative society had a probability of increasing poverty status by 0.21 at $5 \%$ level of significance. This is not expected because co-operative society is supposed to better the life of a member. This effect may be due to complaints of respondents about co-operative societies. These include unfairness, mismanagement of funds and lack of fulfillment of expected benefits. Sex had significant effect at $1 \%$ level and had a probability of increasing poverty status by 0.295 . This may be due to the fact that an average male has more responsibilities than his female counterpart. Marital status increases the probability of being poor by 0.243 and it was significant at 5\%. This means that being married would increase the chances of being poor. The married have more responsibilities. Also, primary and secondary income had negative significant 
relationship with poverty. Although primary income was significant at $5 \%$ while secondary income was significant at $10 \%$. This indicates that earning income from multiple streams is poverty reducing.

Table 5: Probit regression result on effect of income diversification on poverty status

\begin{tabular}{llll}
\hline Variable & z-value & Coefficient & marginal probability \\
\hline Age & 0.014 & $-.0321396^{* *}$ & -.012813 \\
Household size & 0.000 & $.4390539^{* * *}$ & .1750357 \\
Primary occupation & 0.469 & -.2545589 & -.1004824 \\
Secondary occupation & 0.100 & $-.4118469^{*}$ & -.1620918 \\
Farm size & 0.319 & .0358102 & .0358102 \\
Membership to society & 0.014 & $.5499677^{* *}$ & .2192533 \\
Sex & 0.000 & $.5499677^{* * *}$ & .2952942 \\
Marital status & 0.013 & $.6240949^{* *}$ & .2434362 \\
Years of education & 0.686 & -.0112396 & -.0044808 \\
Primary income & 0.019 & $-0.0000001^{* *}$ & -0.0000007 \\
Secondary income & 0.002 & $-0.000008^{* * *}$ & -0.0000032 \\
Log likelihood & & -87.626478 & \\
Pseudo $\mathrm{R}^{2}$ & & 0.3628 & \\
Prob $>\chi^{2}$ & & 0.0000 & \\
$\mathrm{~N}$ & & 200 & \\
\hline
\end{tabular}

Note: $* * *, * *, *$ Coefficients are significant at the $1 \%, 5 \%$, and $10 \%$ level, respectively.

Source: Data Analysis, 2016.

\section{Conclusion}

Rural households diversified from agricultural livelihood activities to non-agricultural activities. Income inequality was higher among households that earned non-agricultural income than households that earned agricultural income, implying that agricultural income is more inequality reducing. Agricultural activities were found to be the predominant livelihood activities among the rural people but it did not reduce poverty significantly, but diversifying into non-agricultural activity as secondary income sources reduced poverty significantly. Nonetheless, income from primary and secondary activities reduced poverty significantly. It is concluded that there was income inequality among the rural households, income diversification (generating income from primary and secondary sources) by households decreased rural households' poverty, implying that livelihood diversification offers an opportunity for alleviating poverty among the rural households through multiple streams of income. Government policy should encourage rural households to remain in the farming business but motivated to harness other potentials in agriculture since agricultural income was found to be income inequality reducing. The policy should also emphasize crop farming since it has the highest share from total income. Skill acquisition programs by government and non-governmental organizations (NGOs) to enhance multiple streams of income (income diversification) for the households will be poverty reducing.

\section{References}

Adepoju, A. O. \& Obayelu 0. A. (2013). Livelihood Diversification and Welfare of Rural households in Ondo State Nigeria. Journal of Development and Agricultural Economics, 5(12), 482-489.

Adigun, G. T., Bamiro, O. M. \& Adedeji, I. A. (2011). Explaining Poverty and Inequality by Income Sources in Rural Nigeria. IOSR Journal of Humanities and Social Science (IOSR-JHSS), 20(3), 61-70.

Aigbokhan, B. E. (2008). Growth, Inequality and Poverty in Nigeria. A CGS/MPAMS Discussion Paper No. 3, United Nations Economic Commission for Africa (UNECA), Addis Ababa, Ethiopia.

Alawode, 0. O., Akubo, J. O. \& Abegunde, V. O. (2016). Agricultural Intensification and Poverty among farmers in Kogi state Nigeria. International journal of Innovative Agriculture and Biology Research, 4(2), 37-45

Asogwa, B. C., Umeh, J. C. \& Okwoche, V. A. (2012). Poverty and Efficiency among the Farming Households in Nigeria: A Guide for Poverty Reduction Policy. Journal of Economic Theory, 4(1), 6-10

Awoyemi, T. T. (2004). Rural Non-Farm and Poverty Reduction in Nigeria. A Report Submitted to AERC, Nairobi, Kenya. 
Barrett, C. B., Reardon, T. \& Webb, P. (2001). Nonfarm Income Diversification and Household Livelihood Strategies in Rural Africa: Concepts, Dynamics, and Policy Implication. Food Policy, 26(4), 315-331.

British Council. (2012). Gender in Nigeria Report: Improving the Lives of Girls and Women in Nigeria, $2^{\text {nd }}$ Edition, British Council, Nigeria. Website: http://www.britishcouncil.org.ng/gender2012

Bryceson, D. F. (1996). Deagrarianisation and Rural Employment in Sub-Saharan Africa: A Sectoral Perspective. World Development, 24(1), 97-111.

Bryceson, D. F. (2002). The Scramble in Africa: Reorienting Rural Livelihoods. World Development, 30(5), 725739.

Clarke, G., Colin, L. \& ZouX, H. (2003). Finance and Income Inequality: Test of Alternative Theories, World Bank Policy Research Working Paper 2984, Washington D.C., World Bank.

Damgaard, C. \& Weiner, J. (2000). Describing Inequality in Plant Size or Fecundity. Ecology, 81, 1139-1142.

Ellis, F. (1999). Rural livelihood diversity in developing countries: Evidence and policy implications. Natural Resources Perspectives Report No. 40. London: Overseas Development Institute.

Ersado, L. (2006). Income Diversification in Zimbabwe: Welfare Implications from Urban and Rural Areas. World Bank Policy Research Working Paper No.3964, July. Washington D.C. The World Bank

Foster, J. E., Greer, J. \& Thorbecke, E. (1984). A Class of Decomposable Poverty Measures. Econometrica, 2(81), 761-766.

Hyewon, K. (2011). Livelihood Diversification in Rural Uganda: Its pattern and contribution to income generation with a focus on the role of social network. School of Oriental and African Studies (University of London).

Idowu, A. O., Awoyemi, T. T., Omonona, B. T. \& Falusi, A. O. (2011). Non-farm Income Diversification and Poverty among Rural Farm Households in Southwest Nigeria. European Journal of Social Sciences, 21(1), 163-176.

International Fund for Agricultural Development (IFAD). (2009). Federal Republic of Nigeria, Country Program Evaluation, September 2009, Report No. 1959-NG, International Fund for Agricultural Development.

Jonasson, E. (2005). Non-farm employment as rural poverty exit path? Evidence from Peru. Sweden: Department of Economics. Lund University.

Kaija, D. (2007). Income Diversification and Inequality in Rural Uganda: The Role of Non-Farm Activities. A paper prepared for the Poverty reduction, Equity and Growth Network (PEGNeT) Conference, Berlin.

Kimenju, S. C. \& Tschirley, D. (2008). Agriculture and Livelihood Diversification in Kenyan Rural Households. Tegemo Institute of Agricultural Policy and Development, Nairobi, Kenya.

Lanjouw, P. (2001). Non-agricultural employment and poverty in rural El Salvador. World Development, 29(3), 529-547.

Lanjouw, J. O. \& Lanjouw, P. (2001). The rural non-farm sector: Issues and evidence from developing countries. Agricultural Economics Journal, 26(2), 1-23.

Lawal, J. O., Omonona, B. T. \& Oyinleye, O. D. (2011). Effects of Livelihood Assets on Poverty Status of Farming Households in South Western Nigeria. Journal of Challenges for Agriculture, food and Natural Resources, 7(1), 1-8.

National Bureau of Statistics (NBS). (2005). Nigeria Living Standards 2004 survey. An overview. National Bureau of Statistics (NBS), Abuja, Nigeria

National Population Commission. (2006). National Census Report.

National Poverty Eradication Program (NAPEP). (2006). www.napep.org. Assessed 20, January 2016.

Nwachukwu, I. N. \& Ezeh, C. I. (2007). Impact of Selected Rural Development Programs on Poverty Alleviation in Ikwuano LGA, Abia State, Nigeria. African Journal of Food, Agriculture, Nutrition and Development, 7(5), 1-17.

Nuhu, M. B. (2007). Property Development as a Panacea to Poverty Alleviation in Nigeria Strategic Integration of Surveying Services, FIG Working Week Hong Kong SAR, China, Pp 3-4

Okafor, A. A. (2004). Poverty and human development in Nigeria: Challenges of the Millennium Development Goals. Great AP Express Pub. Ltd. Nsukka.

Omonona, B. (2010). Quantitative Analysis of Rural Poverty in Nigeria. Brief No. 17. Nigeria Strategy Support Program, International Food Policy Research Institute, Washington, D.C

Oyewole, S. O., Adepoju, S. O. \& Akintola, A. L. (2015). Analysis of income diversification strategies among farm households in Oyo state. Journal of Economics and sustainable development, 6(15). 
Oyo State Agricultural Development Program (OYSADEP). (2001). A report of village listing Survey in Oyo state, pp 1-15 planning, monitoring and Evaluation Department, Oyo State Agricultural Development program, Nigeria.

Rahji, M. \& Fakayode, S. A. (2009). A multinomial logit analysis of agricultural credit rationing by commercial banks in Nigeria. Int. Res. J. Fin. Econ., 24: 91. http://www.eurojournals.com/finance.htm

Wilson, A. M., Wickery, J. A., Brown, A., Langston, R. H. W., Smallshire, D., Wottom, S. \& Vanhinsbergh, D. (2010). Changes in the numbers of breeding Waders on Lowland Wet Grasslands in England and Wales Between 1982 and 2002: Capsule Lapwing, Snipe, Curlew and Redshank Decreased Significantly Between 1982 and 2002, while Over the Same Period Oystercatcher Increased. Bird Study, 52(1), 59-69

Yusuf, S. A. \& Oni, O. A. (2008). Expected poverty profile among rural households in Nigeria. Afr. J. Econ. Pol., 15(1), 139-163. 